American Journal of Economics and Business Administration 3 (4): 618-622, 2011

ISSN 1945-5488

(C) 2011 Science Publications

\title{
Comparison between Financial Ratios Analysis and Balanced Scorecard
}

\author{
${ }^{1}$ Khalad M.S. Alrafadi and ${ }^{2}$ Mazila Md-Yusuf \\ ${ }^{1}$ Graduate Business School, Faculty of Business Management, \\ Universiti Teknology MARA (UiTM), Shah Alam, Malaysia \\ ${ }^{2}$ Institute of Business Excellence, Faculty of Business Management, \\ University Teknology MARA (UiTM)), Shah Alam, Malaysia
}

\begin{abstract}
Financial ratios have long been used as a tool to evaluate the overall financial performance of a company. However, in early 1990s, a new method called Balanced Scorecard has been introduced by Robert Kaplan and David Norton to evaluate the overall controlling of a company. Problem statement: To the best of my knowledge at present there are no letrature review comparing between Financial ratios and Balanced Scorecard. Approach: This study is a conceptual paper comparing between the financial ratios analysis and balanced scorecard method. The objective of this paper is to compare between the benefits and problems of using financial ratios analysis and Balanced Scorecard method in evaluating the overall control of the company. Results: As a result, we found that the Balanced Scorecard is more efficient than financial ratios analysis. Conclusion/Recommendations: Both the balanced scorecard and financial ratios analysis are important tools for evaluating performance. So, we cannot ignore either of them.
\end{abstract}

Key words: Financial tools, financial ratios analysis, balanced scorecard

\section{INTRODUCTION}

There are varied definitions for the concept of control. For example, control is know by some as a system to identify the extent of implementation of the plans of an organization and to what extent they succeed in achieving their goals and objectives, by comparing what has been implemented with the outline of what is to be implemented. The plans are then modified based on the results of the actual implementation, thus improving the organization's ability to achieve its goals and objectives (Wright et al., 1992).

From the definition above, we note that control is a system that attempts to ensure that an organization achieves its objectives through the development of performance targets. The actual performance is then measured and compared with the criteria established to identify the extent of that performance.

In order to be effective, a control system generally consists of the following five elements or steps (Erskine, 1991).

Defining the activity to be evaluated: This means specifying the performance targets and focusing on the most significant elements in each process, which must be measured consistently and objectively. This is then expected to lead to the development of performance standard (Jauch and Glueck, 1988).
Setting the performance standards: This involves developing a set of standards to be used in measuring performance and assessing whether those standards are met. The standards set by management should then be applied as a model to assess performance and serve as a point against which to compare actual performance (Boone and Kurtz, 1992).

Measuring performance: After setting standards to be used in measuring goals, the activity of performance measuring takes place. The most important step in the performance measurement process is the collection of information that presents the actual performance of the activity or of the individual's concerned (Boone and Kurtz, 1992).

Comparing actual performance with the standard: In this step, actual performance is compared with desired performance to determine whether there is a match or a difference between them and whether that difference is acceptable or not. Through this comparison, any gaps can be identified. Corrective procedures should then be taken to fill any gap by identifying the internal and external effects that have an impact on the company (Jauch and Glueck, 1998).

Taking corrective actions: This is the last step in the process of control. According to Boone and Kurtz (1992), there are two options:

Corresponding Author: Khalad M.S. Alrafadi, Graduate Business School, Faculty of Business Management, Universiti Teknology MARA (UiTM), Shah Alam, Malaysia 
- The current process of control is continued if actual performance and desired/ planned performance are the same

- Corrective actions must be taken if actual performance is found to deviate from desired/ planned performance

In order for control process to be effective, it should exhibit of characteristics, namely, it should reflect the nature of the activity of the regulatory system, be safe, clear, accurate and comprehensive. In addition, the system should works on the speed of reporting errors, would be acceptable and flexible. Furthermore, according Shehata (2006), the control process should have continuity, objectivity and be economical and contemporary.

Performance analysis and control (Chun and Chuanyu, 2010): The overall control applied to an entire enterprise is taken as a base unit (Terry, 1985). Terry also states that: Most overall controls are financial.

A performance evaluation system includes different methods that can be used for overall control in companies, such as (http://www.seiobluemountain.com, 25/11/2010).

Written Reports, through which managers identify whether there is an efficient level of implementation, by comparing between standard and actual performance Written Reports, 2010.

Internal auditing, which can be defined as the inhouse evaluation of accounting and financial performance of an organization. Internal Auditing also evaluates the various aspects of operational performance Internal Auditing, 2010.

Total Quality Management (TQM) which is a management method used to plan for long-term success by concentrating on customer satisfaction. TQM depends on the participation of all employees of an organization in improving process, products, services and the culture in which they work Total Quality Management, 2010.

Dashboard, which is a significant set of indicators and information that provides an overview of the whole organization and reveals any disturbances. It also enables management to make decisions and establish guidance to achieve the stated goals within the strategy of the organization.

In addition, there are the methods of financial ratios analysis and the balanced scorecard, which are the focus of this study. Here, we attempt to compare financial ratios analysis, a traditional control method, with the balanced scorecard, a more recent control method, in order to ascertain which is the most effective.
Financial ratios analysis: Financial ratios analysis using financial ratios is the most important and oldest method for analysis company performance. It has long been used to study the financial and credit position of organizations and to judge the results of their work. This method is based on the examination of financial statements. However, just because a number is included in a financial statement does not indicate whether that number is important and does not give us useful information; the importance of the number appears only when compared with other number (Tofeeq, 1997). Brigham and Ehrhardt (2010) state "financial ratios are designed to help evaluate financial statements". Financial ratios are used as a planning and control tool.

Financial ratios analysis is used to evaluate the performance of an organization: it aims to determine the strong and weak points and it offers solutions by providing appropriate plans. A large number of standards and various financial ratios can be used when analyzing the credit and financial position of organization. The choice of ratios used depends on the activity of the organization and the purpose of analysis (Tofeeq, 1997).

Most researchers divide the financial ratios into four groups (Ross et al., 2007).

Liquidity ratios: Indicate the organization's ability to pay dept in short term.

Activity ratios: Are "used to measure the speed with various accounts are converted into sales or cash". They are also used to measure how efficiently a company managers their assets (http://www.missouribusiness.net, 12/10/2010).

Dept ratios: Show how effectively the organization uses other people's money and whether it is using a lot of borrowed money (Lasher, 2005).

Profitability ratios: Consist of several measures by which to assess the organization's success in making money (Lasher, 2005).

The nature of the organization influences the ratios employed. For example, in the case of a bank, the liquidity ratio is used to determine the amount of liquidity that a bank needs in order to meet its liabilities; a bank also uses profitability ratios (Tarawneh, 2006). Industrial organizations focus on profitability and activity ratios. On the other hand, nonprofit organizations attempt to get enough financial resources to continue their activities, so they tend to focus on dept ratios. 
The benefits of financial ratios analysis: Financial ratios are an important and well-established technique of financial analysis. The following are the benefits of financial ratios analysis (Lermack, 2003): Firstly, they can be used to evaluate performance and to set standards for performance. Secondly, they can be used to focus on areas that need to be improved or focus on areas that offer the most promising future potential; and thirdly, they enable external parties to assess the creditworthiness/profitability of an organization.

The limitations of financial ratios analysis: Although the use of financial ratios is widespread, they do have their limitations, which can be summarized as follows (Lermack, 2003): Firstly, there is considerable subjectivity involved as there is no theory as to what should be the right number for the various ratios. Secondly, ratios may not be accurately comparable across different companies due to a variety of factors such as different accounting practices, different financial year. Thirdly, ratios are based on financial statements that reflect the past only and are not an indication of the future. Fourthly, financial statements provide an estimation of the costs and not values. The fifth limitation is that financial statements do not include all items. The sixth limitation is that accounting standards and practices vary across countries and this hampers meaningful global comparisons. The seventh limitation relates to decision making; management decision making is a dynamic process in a constantly changing environment, whereas ratios analysis is static because it is based on historical data. Finally, the linkages between different ratios are not always immediately obvious.

Balanced scorecard analysis: The concept of the Balanced Scorecard originate in the early 1990s, when the Nolen Norton Institute commissioned a study entitled, 'Performance Measurement Facility in the future', which involved 12 organizations from different fields. The Institute was the prime mover of the study, convincing the participants that the method for measuring the performance of traditional data as represented by the historical and financial control systems was no longer able to serve its purpose in assisting managers to make decisions (http://www.world-acc.net, 06/05/2010).

Kaplan and Norton (2000) define the Balanced Scorecard as a comprehensive system to measure performance from a strategic perspective which is translating the strategic of business organizing to strategic objectives, measures, targets and preliminary and clear procedural steps. Kaplan and Norton defined the balanced scorecard in 1992 as "one of the most successful, endurable management concepts in recent years" (Olve et al., 2004). According to Frigo (2002), the Balanced Scorecard is a management tool that uses a combination of financial and non-financial measures to evaluate the performance of an organization. So, the Balanced Scorecard is an overall control tool. The Balanced Scorecard is based on the idea that managers must evaluate the performance of their organization by looking at it from four perspectives, namely, financial, customer, internal business process and learning and growth (Philip, 2008). These four perspectives provide the framework for the balanced scorecard (Fig. 1).

The perspectives shown in Fig. 1 are contained in four like-named scorecards, the financial card, the customer card, the internal processes card and the learning and innovation card, as follows (Kaplan and Norton, 1996).

Financial card: This card contain purely financial targets such as return on investment, cost of products, profitability, cash flow, which are used to measure the financial ratios and different financial figures. It is important to pick those numbers which depict important financial and expressive performance of the work of an organization. For example, if we focused only the value of net profit, this might not be adequate information, because although the net profit may be considerable, the return on investment may only be small. It may also be that some financial figures reflect the task at the time, such as cash flow in times of intractability. The situation in non-profit organizations may be different, but in the end they too have to maintain sufficient resources.

Customer card: This card contains targets for customer satisfaction, such as achieving the wishes of customers through products or providing new services, responding to customer complaints, improving service or method of selling, increasing product knowledge. If an organization does not track customer requests and complaints, there is a danger that its customers will go to another competitor to achieve their desires.

The internal processes card: This card is concerned with developing an organization internally so that a high level of performance is maintained in operations. This card may include such goals as quality manufacturing, the speed of change of production of a product for another product, the development of management system, use of information technology, cooperation between different departments and other goals related to internal processes. 


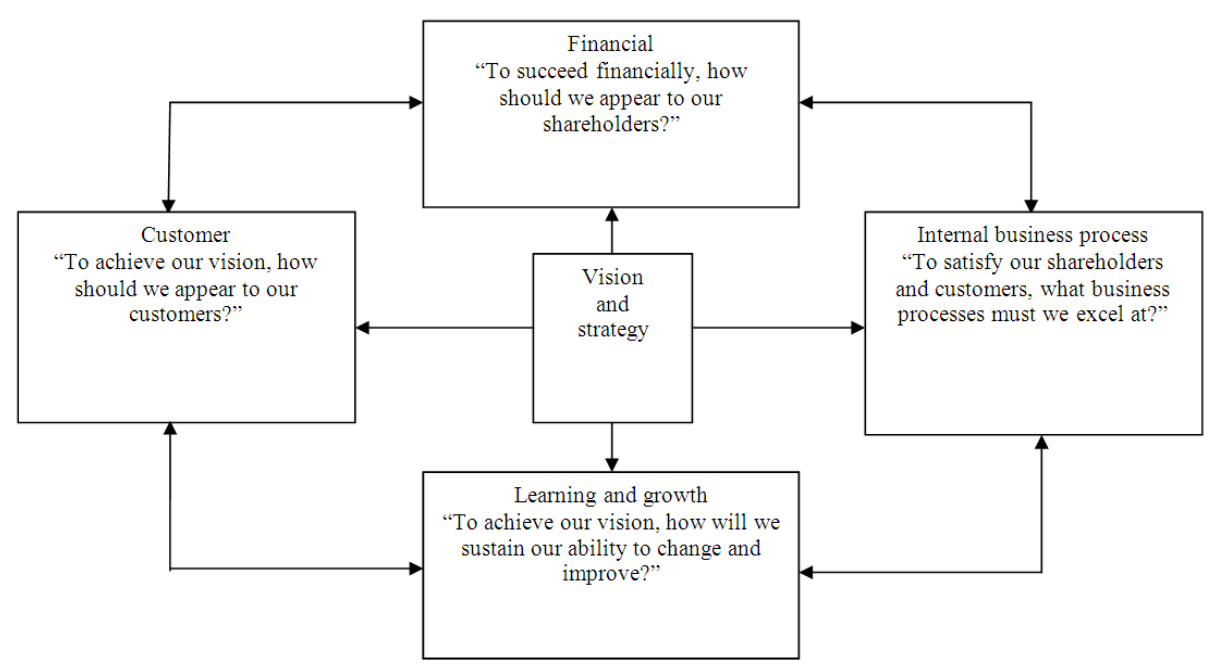

Fig.1: The Balanced Scorecard frame Source: Robert S. Kaplan and David P. Norton, "Using the Balanced Scorecard as a strategic Management system”, Harvard Business Review (Jan- Feb- 1996): 76

In many organizations, many of the performance measures for internal processes are largely neglected and therefore the organizations are not improving their level of performance, it is in fact declining.

Learning and innovation card: This card focuses on organization's ability to develop new products, learn, or create advanced and modern management policies. Without learning and innovation an organization cannot continue because competitors will evolve and that organization will fall behind the competition.

The balanced scorecard is used to evaluate overall performance by setting standards for each perspective that makes up the Balanced Scorecard; these perspectives should be measured to achieve strategic goals of an organization.

Benefits of the balanced scorecard: The balanced scorecard has three main benefits. Firstly, it focuses on the whole organization as a one unit by using a few basic items that are needed by the organization to innovate. Secondly, it helps to integrate the various programmers of the organization such as quality, reengineering and customer service initiatives. Thirdly, it sets out the standards of the strategy for lower levels of the organization, such as unit managers and employees. The employees can determine the special demands to achieve excellent overall performance History of Balanced Scorecard, 2010.

Problems of the balanced scorecard method: While there are benefits to using Balanced Scorecard, there are a few problems associated with the method as well. Firstly, the Balanced Scorecard cannot solve all problems; it is not a tool to improve an organization, rather, it helps to achieve an organization's strategy. Secondly, the financial, customer, internal business process and learning and growth cards are tools to determine balanced goals only. So, if there is no followup, that is, no implementation of management policies to make the necessary improvements, then the balanced scorecard will fail. Thirdly and importantly, many organizations use metrics that are not applicable to their own situation. It is important when using the Balanced Scorecard to ensure that the information being tracked is applicable. Otherwise, the metrics will be meaningless (http://www.brighthub.com, 15/11/2010).

Comparison of financial ratios analysis and the balanced scorecard: The objective of this study is to compare the effectiveness of financial ratios analysis and the balanced Scorecard method in evaluating the overall control of a company. In this part, we will compare them according to their benefits and limitations. The questions that we should ask are: (1) is financial ratios analysis an adequate method to evaluate overall performance of an organization or not? and (2) which method is the more efficient?

Both financial ratios analysis and Balanced Scorecard are used to evaluate the overall performance of a company, but the Balanced Scorecard gives a full picture as to whether a company is meeting its objectives. The Balanced Scorecard sets standards against which to measure performance. Moreover, the 
Balanced Scorecard sets standard to lower levels in the management structure.

Both financial ratios analysis and the balanced scorecard measure performance. However, financial ratios analysis measures the performance in the short term because it focuses on financial measurements only, whereas the Balanced Scorecard measures the performance in both the short and the long term because it focuses on financial and non-financial measurements. Also, financial ratios reflect the past only because they are based on historical data. In contrast, we can use the Balanced Scorecard to evaluate potential future performance. Financial ratios analysis is a static analysis because it is based on historical data, so it is not suitable for management decision making because the business environment is always changing. In contrast, the balanced scorecard is a dynamic analysis, so, it is suitable for management decision making in the evolving business environment.

Financial ratios analysis focus on financial results that reflect the owners' perspective, whereas the Balanced Scorecard focuses on financial and nonfinancial results that reflect not only the owners' perspective, but also the customer perspective, internal process perspective and learning and growth perspective.

From the above, we can conclude that financial ratios analysis is not an adequate method by which to evaluate the overall performance of an organization; also the balanced scorecard is more efficient than financial ratios analysis.

\section{CONCLUSION}

Financial ratios analysis and the balanced Scorecard are tools that assess overall control and are used to evaluate the performance of an organization. The contribution of this study is that it identifies which method is more efficient by comparing the benefits and limitations of financial ratios analysis and the Balanced Scorecard. The study examined whether financial ratios analysis is adequate or not use as an evaluation tool to assess the overall performance of an organization.

As a result, we found that the Balanced Scorecard is more efficient than financial ratios analysis because the latter is not comprehensive enough to evaluate overall performance.

Nevertheless, both the balanced scorecard and financial ratios analysis are important tools for evaluating performance. So, we cannot ignore either of them.

\section{REFERENCES}

Boone, L. and D. Kurtz, 1992. Management. 2nd Edn. McGraw-Hill, Inc., New York, USA.
Brigham, E.F. and M.C. Ehrhardt, 2010. Financial Management Theory and Practice. 13th Edn., South-Western Cengage Learning, Mason, OH, ISBN: 1439078106 , pp: 1184.

Erskine, R. 1991. Business Management. Prentice Hall International, UK

Frigo, M., 2002. Financial ratios, Strategy and the balanced scorecard. Strategic Finance, 84: 6-9.

Jauch, L.R. and W.F. Glueck, 1988. Business Policy and Strategic Management. 5th Edn., McGrawHill, USA., ISBN: 0071005072, pp: 940.

Kaplan, R.S. and D.P. Norton, 1996. The Balanced Scorecard: Translating Strategy into Action. 1st Edn., Harvard Business School Press, Boston, Mass., ISBN: 0875846513, pp: 322.

Kaplan, R.S. and D.P. Norton, 2000. The Balanced Scorecard: Measures that Drive Performance. 1st Edn., Harvard Business School Publishing, Boston Mass., ISBN: 1578514096, pp: 10.

Lasher, W.R., 2005. Practical Financial Management. 4th Edn., South-Western College Pub., USA., ISBN-10: 0324260768, pp: 784.

Lermack, H., 2003. Steps to a basic company financial analysis. Philadelphia University, Philadelphia, USA.

Chun, L. and Q. Chuanyu, 2010. Improving performance evaluation model for business organizations based on social responsibility contribution. School of Economics and Management, Beijing Information Science and Technology University, China.

Olve, N.G., C.J. Petri, J. Roy and S. Roy, 2004. Twelve years later: Understanding_and realizing the value of balanced scorecard. Ivey Bus. J., 1-7.

Philip, A., 2008. Managing performance in intermediate care services-A balanced scorecard approach. School of Management, Blekinge Institute of Technology.

Ross, S., R. Westerfield, B. Jordan, A. Mazin and Z.F. Abidin et al., 2007. Financial management fundamentals in Malaysia. McGraw-Hill, Malaysia.

Shehata, H., 2006. The foundations of overall control in Islamic banks, a series of research and studies in the Islamic economic though. Al-Azhar University, Egypt.

Tarawneh, M., 2006. A comparison of financial performance in the banking sector: Some evidence from Omani commercial banks. Int. Res. J. Finance Econ., 101-112.

Terry, G., 1985. Principles of Management. Irwin, Illinois.

Tofeeq, J., 1997. Principles of financial management, Alexandria. Modern University Office, Egypt.

Wright, P., C. Pringle and M. Kroll, 1992. Strategic management (text and cases). 